\title{
ANALYSIS OF ABNORMAL RETURN AND VOLUME ACTIVITY OF TELECOMMUNICATIONS SECTOR SHARES IN INDONESIA BEFORE AND AFTER COVID-19
}

\section{Sumadi, Dewi Tamara, Purba Yudha Tama, William}

Binus Business School, Binus University Jakarta,Indonesia

Email: sumadiajah@gmail.com,dtamara@binus.edu,purba.yudha@gmail.com, william.hendarpo@gmail.com

\begin{abstract}
The study intends to investigate if there are significant differences in the abnormal return and volume activity of telecommunication companies 90 exchange days before and 90 exchange days after the announcement of the first Covid-19 infection in Indonesia with the Event Study method. The strategies used in this study are quantitative methods with statistical description analysis using different t-test with paired samples. The samples used in this study are EXCL, ISAT, and TLKM companies included in the telecommunications infrastructure sector and listed on the Indonesia Stock Exchange (IDX). The research test results showed that there was no significant difference in the abnormal return and trading volume activity of telecommunication companies in Indonesia. It proves that telecommunication companies' performance in Indonesia is not affected by the Covid-19 pandemic, because the demand for internet and telecommunication services has become the basic need for people to be able to maintain their productivity at home.
\end{abstract}

Keywords: abnormal return; trading volume activity; event study; telecommunication sector

Received: 2021-09-22; Accepted: 2021-10-05; Published: 2021-10-20

\section{Introduction}

The emergence of the Covid-19 virus pandemic has a significant impact on all aspects of life, especially macro and microeconomic also local and global economic conditions. The impact of this significant decline was especially felt at the time of Covid-19 announcement as pandemic by WHO on Wednesday March 11, 2020 after the number of infections worldwide reached more than 121,000 cases (Utomo et al., 2020) from the first reported case of Corona Virus Disease 2019 in Wuhan, China on November 17, 2019 (Yeremia, 2021).

Various steps were taken by each country to cope with the spread of Corona Virus Disease 2019. The Indonesian government uses the PSBB (Large-Scale Social Restriction) policy by closing tourist attractions, shopping malls and eliminating teaching and learning activities in schools (Sutrisna, 2020) after it was announced on March 2, 2020 the first Covid infection in Indonesia. The overall restrictive policy made

\begin{tabular}{ll}
\hline How to cite: & Sumadi., Tamara,D., Tama,P,Y., William (2021) Analysis Of Abnormal Return And Volume \\
& Activity Of Telecommunications Sector Shares In Indonesia Before And After Covid-19, Syntax \\
& Idea, 3(11), https: doi.org/10.36418/syntax-idea.v3i11.1574 \\
E-ISSN: & 2684-883X \\
Published by: & Ridwan Institute
\end{tabular}


Indonesia's economy throughout 2020 contract by minus $2.07 \%$, according to the BPS (Central Statistics Agency) (Candra et al., 2021).

If we doing in depth examination, there are businesses in some industrial sectors that are severely affected, but there are also industrial sectors that actually get opportunities from the implementation of policies to combat the spread of Covid-19. For example, the telecommunications sector which experiencing a significant increase in the demand for internet services. It can be seen from the increase in new orders for Internet services and cable TV companies (Indihome), which increase by $47 \%$ in 2020 due to the policy to conduct activities from home, such as studying and working from home, said Ahmad Reza, SVP Corporate Communication and Investor Relations (Utami, 2020). But when compared to the rate of return on its shares, Telkom's share price (TLKM) actually experienced a significant decrease of $-19.18 \%$ with an increased share trading volume, between January 2, 2020 and March 31, 2020 (first quarter of 2020).

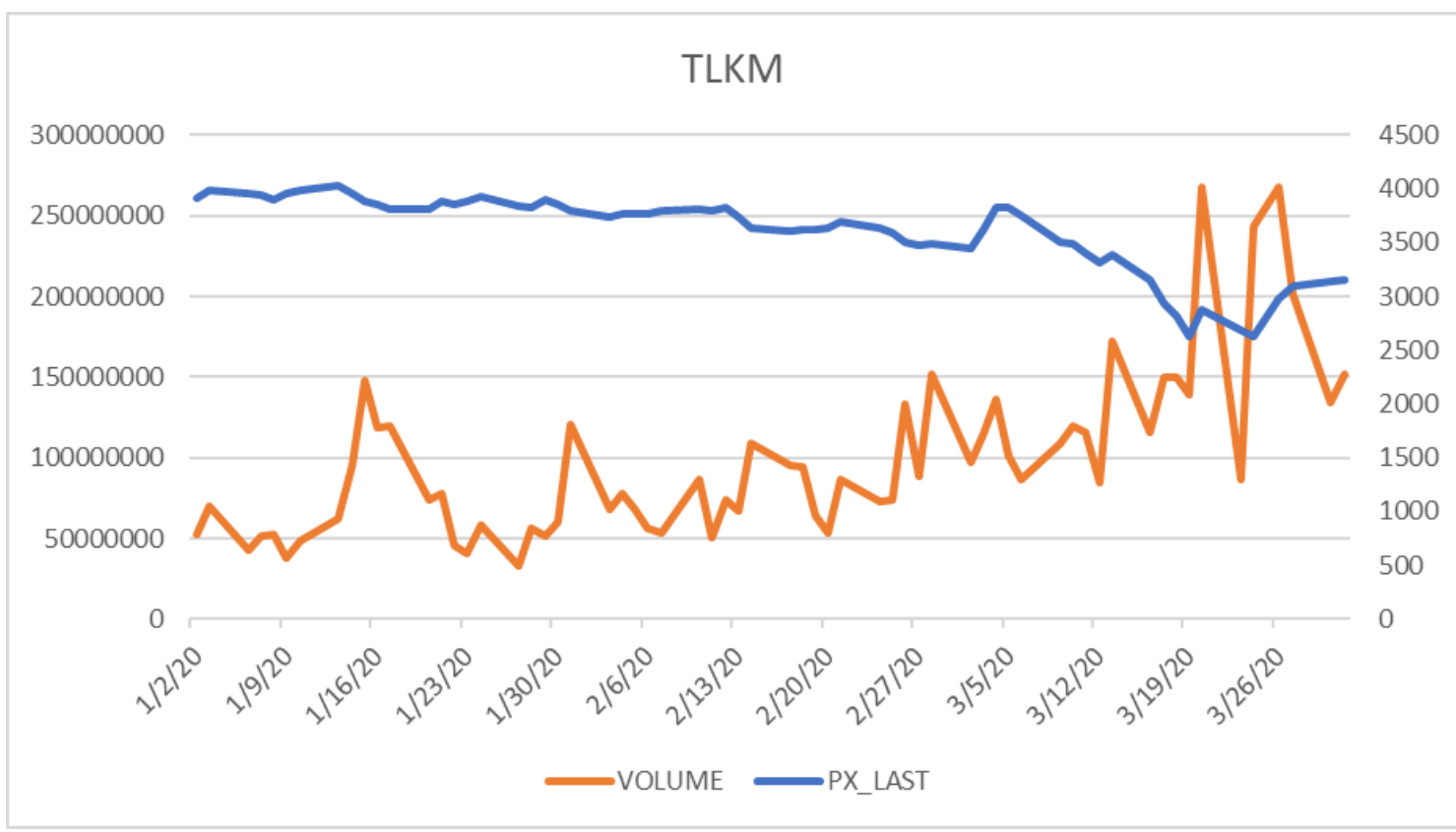

Figure 1

Stock Price and Trading Volume Telkom Jan - Mar 2020

The anomaly between the positive performance of telecommunications companies with differences in abnormal return and stock trading volume makes this study important to be analyzed. First, for financiers who want to invest in the stock market during pandemic, this research could be used as consideration, so the decision will be more accurate and avoiding them from potential losses. Second, this study can become reference for researchers who want to conduct follow-up studies, especially related to stocks abnormal returns and trading volume. Third, this study can be a reference for the management of telecommunications sector industry to make the right decisions in 
responding to stock market volatility, especially in unexpected conditions such as the Covid-19 Pandemic.

According to (Rahmayani \& Oktavilia, 2020) stated that the existence and effect of the pandemic in Indonesian stock market has negative effect. Their study utilized the Error Correction Model where the stock market acted as an endogenous variable, and the exogeneous variables are commodity price, pandemic and exchange rate, among others. The objective of this research is to identify the effect of pandemic in telecommunication industry, as the industry who reaps the benefit because the lockdown situation and everybody works and school at homes.

\section{Research Methods}

Researchers used the Event Study method in their research to compare AR and TVA of each sample on -90 exchange days before October 22, 2019 and +90 exchange days after the announcement of the first Corona Virus Disease 2019 infection in Indonesia on March 2, 2020, which is July 16, 2020. The strategy used by researchers in this study are quantitative method with statistical description test analysis using daily secondary data (AR and TVA) of each sample so the results could be more accurate (Aprillia, 2020).

Researchers used different t-test technique with paired sample to analyze hypothesis 1 of significant differences in AR before and after the first announcement of 2019 Corona Virus Disease event in Indonesia. Where the stages to test hypothesis 1 are: 1) Perform daily stock return calculations to look for $\mathrm{R}_{\mathrm{it} .}$ 2) Calculate the expected return adjusted to the level of risk of the stock (CAPM). 3) Perform abnormal return calculations from each sample. 4) Calculate the statistical description of AR before and after the events of each sample. 5) Perform a sample t-test paired with a significance level of $\alpha$ 0.05. 6) Decides H0 and Ha.7) Determines whether to approve H0 (if sig. > of the significance level $\alpha(0.05)$ ), or refuse $\mathrm{H} 0$ and approve $\mathrm{H} 1$ or $\mathrm{Ha}$ (if sig. < from the significance level $\alpha(0.05)$ (Faulan, 2020).

While the technique used by researchers to analyze hypothesis 2 related to significant differences in TVA before and after the announcement of the first Corona Virus Disease 2019 infection in Indonesia are using different test $t$ test with paired sample. Where the test stages of hypothesis 2 are: 1) Determine the TVA of each sample in the event window. 2) Perform a calculation of TVA statistical descriptions before and after the occurrence of each sample. 3) Perform a paired t test at a significant rate of $\alpha 0.05 .4$ ) Decide on $\mathrm{H} 0$ and Ha. 5) Determine whether to approve H0 (if sig. > of the significance level $\alpha(0.05)$ ), or refuse $\mathrm{H} 0$ and approve $\mathrm{H} 1$ or $\mathrm{Ha}$ if sig. < from the significance level $\alpha$ (0.05) (Fajriani, 2021).

The involvement of researchers in the data collection technique in this study is minimal because the source of this study data comes from secondary data, namely daily stock closing price data and daily stock trading volume that can be obtained from the Indonesia Stock Exchange. Where the study setting in this study is non-contrived, in which the research is carried out in the normal environment activities. 
The population in this study are telecommunications sector company listed on the Indonesia Stock Exchange (IDX). Where the public need for internet services provided by telecommunication companies increased during the Covid-19 pandemic. Therefore researchers wanted to examine whether there were significant differences in AR and TVA telecommunications sector companies before and after the announcement of the first Covid infection in Indonesia. The population in this study consists of 6 companies in telecommunications sector on the Indonesia Stock Exchange, namely Bakrie Telecom Tbk. (BTEL), XL Axiata Tbk. (EXCL), Smartfren Telecom Tbk. (FREN), Indosat Tbk. (ISAT), Jasnita Telekomindo Tbk. (JAST) and Telekomunikasi Indonesia Tbk. (TLKM). The sample that will be used in this study are EXCL, ISAT and TLKM, considering that the three companies have relatively the same stock price range that are in the range of thousands, unlike BTEL whose stock price tends to stagnate in the tens range and FREN and JAST whose share price ranges are in the hundreds.

The time horizon or time dimension specified in this study is longitudinal studies, which means the study was measured at several points of time using the same sample, 90 exchange before the announcement of the first Corona Virus Disease 2019 infection in Indonesia on March 2, 2020, namely October 22, 2019 and +90 exchange days after the announcement of the first Corona Virus Disease 2019 infection in Indonesia, July 16, 2020.

\section{Results and Discussions}

\section{A. Description Statistic Test Analysis}

After the calculation of Abnormal Return and TVA of each sample using secondary data and formulas that have been submitted on theoretical review, the results will be used to test statistical descriptions to find out the lowest, highest, mean and standard deviation values of AR and TVA before and after the announcement of first Covid-19 infection in Indonesia. The results of the description statistic test can be seen in tables 1 and 2, as follows.

\section{Table 1}

Statistical Description Test of AR

\begin{tabular}{ccccccc}
\hline & & N & Minimum & Maximum & Mean & $\begin{array}{c}\text { Std. } \\
\text { Deviation }\end{array}$ \\
\hline TLKM & AR Before & 90 & $-0,0231908$ & 0,0396121 & 0,006866153 & 0,016106135 \\
\cline { 2 - 7 } & AR After & 90 & $-0,2642194$ & 0,1245318 & 0,002363389 & 0,050573131 \\
\hline \multirow{2}{*}{ ISAT } & AR Before & 90 & $-0,0761463$ & 0,1262432 & 0,028241644 & 0,033211278 \\
\cline { 2 - 7 } & AR After & 90 & $-0,1743374$ & 0,1627799 & 0,016133408 & 0,061829847 \\
\hline EXCL & AR Before & 90 & $-0,0327514$ & 0,0713995 & 0,013524156 & 0,022268237 \\
\cline { 2 - 7 } & AR After & 90 & $-0,1787594$ & 0,1363195 & 0,005163464 & 0,057876243 \\
\hline \multicolumn{5}{c}{ Source: Secondary data processed, 2021 } &
\end{tabular}

Table 1 is the result of statistical description of the Variable Abnormal Return (AR), where the data shows that in TLKM AR, the lowest value before the first Covid- 
19 infection announced in Indonesia was -0.0231908, with the highest value of 0.0396121 , the mean value of 0.006866153 and the standard deviation of 0.016106135 . While at the time after the announcement of the first Covid-19 infection in Indonesia the minimum variable value of TLKM AR became -0.2642194 , with a maximum value of 0.1245318 , an average value of 0.002363389 and standard deviation of 0.050573131 . TLKM AR analysis shows deviations from the average variable, where the standard deviation value is higher than the mean variable value. In addition, the difference between the minimum and maximum of TLKM AR which before $(0.0628029)$ and after $(0.3887512)$ the announced the first Covid-19 case became even greater, indicating that there are increasing in volatility of TLKM AR after the announcement of the first infection of Corona Virus Disease 2019 in Indonesia.

While in ISAT AR, the lowest value before the announcement of the first Corona Virus Disease 2019 infection in Indonesia was -0.0761463 , with the highest value of 0.1262432 , the mean value of 0.028241644 and standard deviation of 0.033211278 . While at the time after the announcement of the first Covid-19 infection in Indonesia the lowest value of variable ISAT AR -0.1743374, with the highest value 0.1627799 , mean value of 0.016133408 and standard deviation of 0.061829847 . ISAT AR analysis shows deviations from the variable average, where the standard deviation value is higher than the mean variable value. In addition, the difference between the minimum and maximum value range of ISAT AR, before (0.2023895) and after (0.3371173) announced the first Covid-19 case becomes even greater, this indicates the increasing volatility in ISAT AR after the announcement of the first Corona Virus Disease 2019 infection in Indonesia.

In AR EXCL, the minimum value before the announcement of the first Corona Virus Disease 2019 infection in Indonesia was -0.0327514, with a top value of 0.0713995 , mean value of 0.013524156 and standard deviation of 0.022268237 . While at the time after the announcement of the first Covid-19 infection in Indonesia the lowest value of variable EXCL AR to -0.1787594 , with top value of 0.1363195 , mean value of 0.005163464 and standard deviation of 0.057876243 . This analysis of AR EXCL shows deviation from the average value of the variable, where the standard deviation value is higher than the mean variable value. In addition, the difference between the minimum and maximum EXCL AR value range, before (0.1041509) and after (0.3150789) was announced the first Covid-19 infection became even greater, indicating a higher volatility in EXCL AR after the announcement of the first Covid-19 infection in Indonesia.

If we examined the difference between the minimum and maximum AR value ranges of TLKM, ISAT and EXCL before and after Indonesia announced the first case of Covid-19 infection, it can be seen that TLKM AR has the largest range of values where the difference between the AR values before and after are 0.3259483 , followed by EXCL and ISAT. This shows that TLKM AR are more affected and impacted from the announcement of the first Covid-19 infection in Indonesia. 
Sumadi, Dewi Tamara, Purba Yudha Tama, William

Table 2

Statistical Description Test of Trading Volume Activity

\begin{tabular}{ccccrrr}
\hline & N & Minimum & Maximum & Mean & $\begin{array}{c}\text { Std. } \\
\text { Deviation }\end{array}$ \\
\hline \multirow{2}{*}{ TLKM } & TVA Before & 90 & $-0,6171523$ & 1,8817440 & 0,099525807 & 0,524941469 \\
\cline { 2 - 7 } & TVA After & 90 & $-0,6575865$ & 2,1070497 & 0,096137221 & 0,473505932 \\
\hline \multirow{2}{*}{ ISAT } & TVA Before & 90 & $-0,8405688$ & 7,1990645 & 0,252968800 & 0,958530933 \\
\cline { 2 - 7 } & TVA After & 90 & $-0,9724056$ & 23,6168653 & 0,592018667 & 2,88868312 \\
\hline \multirow{2}{*}{ EXCL } & TVA Before & 90 & $-0,8633256$ & 8,8173790 & 0,202268262 & 1,07549031 \\
\cline { 2 - 7 } & TVA After & 90 & $-0,8862110$ & 2,6864118 & 0,143306553 & 0,576880960 \\
\hline \multicolumn{3}{c}{ Source: Secondary data processed, 2021} & &
\end{tabular}

Table 2 are the result of statistical description test of Trading Volume Activity (TVA) variable, where the data shows that for TLKM TVA, the minimum value before the announcement of the first Covid-19 infection in Indonesia is -0.6171523 and the highest value is 1.8817440 , the mean value is 0.099525807 and the standard deviation is 0.524941469. While at the time after the announcement of the first Covid-19 infection in Indonesia the minimum variable value of TLKM TVA became -0.6575865 , with a maximum value of 2.1070497 , a mean value of 0.096137221 and a standard deviation of 0.473505932 . This TLKM TVA analysis shows the deviation from the average variable, which the standard deviation value is greater than the average value of the variable. In addition, the difference between the minimum and maximum value range of TLKM TVA, before (2.4988963) and after (2.7646362) announced of first Covid-19 case became even greater, this indicates the increasing volatility in TLKM TVA after the announcement of the first Corona Virus Disease 2019 infection in Indonesia.

As for ISAT TVA, the minimum value before the announcement of the first Covid-19 infection in Indonesia amounted to -0.8405688 and the highest value was 7.1990645 , the mean value was 0.252968800 and the standard deviation was 0.958530933. While at the time after the announcement of the first Covid-19 infection in Indonesia the minimum variable value of ISAT TVA became -0.9724056 , with a maximum value of 23.6168653, a mean value of 0.592018667 and a standard deviation of 2.88868312. This ISAT TVA analysis shows deviation from the average variable, where the standard deviation value is greater than the mean variable value. In addition, the difference between the minimum and maximum value range of ISAT TVA, before (8.0396333) and after (24.5892709) the announcement of the first Covid-19 infection became even greater, this indicates the increasing volatility in ISAT TVA after the announcement of the first Corona Virus Disease 2019 infection in Indonesia.

For TVA EXCL, the minimum value before the announcement of the first Covid19 infection in Indonesia was -0.86333256 and the highest value was 8.8173790 , the mean value was 0.202268262 and the standard deviation was 1.07549031 . While at the time after the announcement of the first Covid-19 infection in Indonesia the minimum variable value of TVA EXCL became -0.8862110, with a maximum value of 2.6864118 , a mean value of 0.143306553 and a standard deviation of 0.5768880960 . 
This TVA EXCL analysis shows deviation from the average variable, where the standard deviation value is higher than the mean variable value. In addition, the difference between the minimum and maximum value range of TVA EXCL, before (9.68071156) and after (3.5726228) the announcement of the first Covid-19 infection became even greater, indicating lower volatility in EXCL TVA after the announcement of the first Covid-19 infection in Indonesia.

When examined the difference between the minimum and maximum value ranges of TVA TLKM, ISAT and EXCL before and after Indonesia announced the first case of Corona Virus Disease infection 2019, it can be seen that ISAT TVA has the largest range of values where the difference between the values of TVA range before and after is 16.5496376 , followed by TLKM of 0.2657399 . This proves that ISAT TVA increased more significantly after the announcement of the first Covid-19 infection in Indonesia. Unlike EXCL whose TVA value range decreased after the announcement of the first Covid-19 infection in Indonesia, it indicates the trading volume activity tends to be decreased.

Hypothesis Test

Testing of hypothesis 1 and hypothesis 2 will be done as follows:

HO

$\square 1=\square 2$

H1 : $\quad \square 1 \neq \square 2$

$\mathrm{HO}$ is accepted if the significance level is higher than $\alpha(0.05)$, but $\mathrm{H} 0$ is rejected if the significance level is smaller than $\alpha(0.05)$.

\section{First Hypothesis}

In the first hypothesis it is stated that there are significant difference in AR of telecommunication companies shares before and after the announcement of the first corona virus disease case in Indonesia. To find out the value of significance in the first hypothesis, the $t$ test is performed using pair sample with significance level $\alpha$ of 0.05 , the results found are:

Table 3

AR Paired Sample Test

Paired Differences

Significanc

e

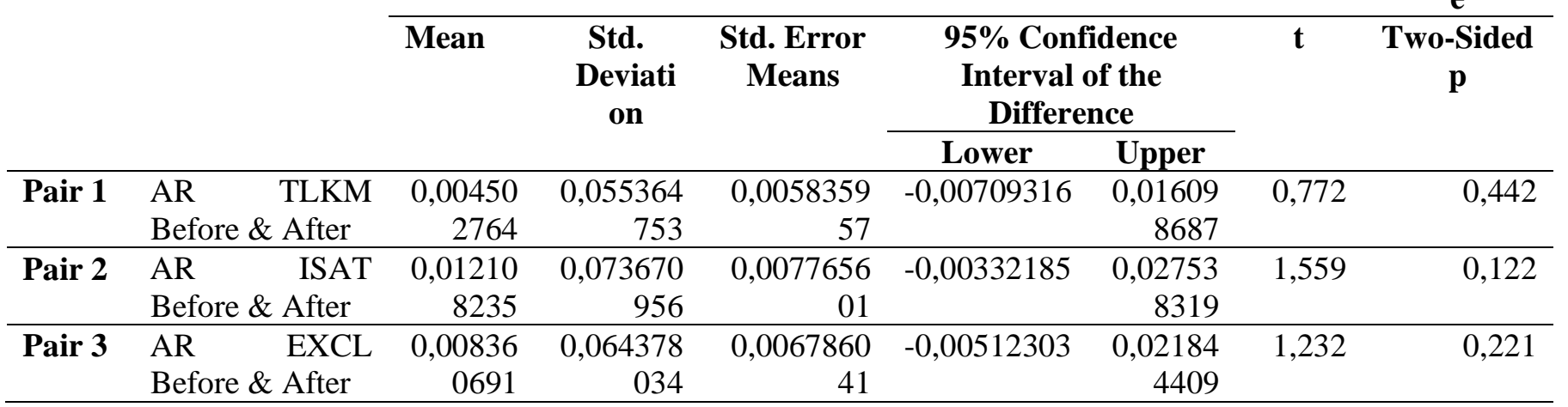

Source: Secondary data processed, 2021 
From the results of the AR paired test which can be concluded in Table 3, the significant level of the three samples are higher than 0.05 , where TLKM had a significance level of 0.442 with $t$ count value of 0.772 , while ISAT showed a significant level of 0.122 with t count value of 1.559 and EXCL had a significance level of 0.221 with $t$ count value of 1.232 . Based on these results, we can see that there was no significant difference in the three samples, therefore it can be concluded that $\mathrm{H} 0$ of telecommunications sector companies (TLKM, ISAT and EXCL) abnormal return before and after the announcement of first case of Corona Virus Disease 2019 infection in Indonesia are accepted. Therefore, the first hypothesis is rejected

\section{Second Hypothesis}

In the second hypothesis it is mentioned that there are significant differences in TVA shares of telecommunications sector companies before and after the announcement of the first Covid-19 infection in Indonesia. To find out the value of significance in the second hypothesis, the paired t test is performed at a significance level of $\alpha 0.05$, so that the following results are found:

Table 4

TVA Related Sample Test

\begin{tabular}{|c|c|c|c|c|c|c|c|c|}
\hline & & \multicolumn{5}{|c|}{ Paired Differences } & \multicolumn{2}{|r|}{ Significance } \\
\hline & & \multirow[t]{2}{*}{ Mean } & \multirow[t]{2}{*}{$\begin{array}{c}\text { Std. } \\
\text { Deviation }\end{array}$} & \multirow[t]{2}{*}{$\begin{array}{l}\text { Std. Error } \\
\text { Means }\end{array}$} & \multicolumn{2}{|c|}{$\begin{array}{l}\text { 95\% Confidence Interval } \\
\text { of the Difference }\end{array}$} & \multirow[t]{2}{*}{$\mathbf{t}$} & \multirow[t]{2}{*}{ Two-Sided p } \\
\hline & & & & & Lower & Upper & & \\
\hline \multirow[t]{2}{*}{ Pair 1} & TVA TLKM & 0,003388 & 0,67412238 & 0,07105873 & - & 0,14458078 & 0,048 & 0,962 \\
\hline & $\begin{array}{l}\text { Before \& } \\
\text { After }\end{array}$ & 586 & 1 & 8 & 0,13780361 & 5 & & \\
\hline \multirow[t]{3}{*}{ Pair 2} & $\begin{array}{ll}\text { TVA } & \text { ISAT }\end{array}$ & - & 3,03224535 & 0,31962672 & - & 0,29604162 & $-1,061$ & 0,292 \\
\hline & Before \& & 0,339049 & & 5 & 0,97414136 & 7 & & \\
\hline & After & 87 & & & & & & \\
\hline \multirow[t]{2}{*}{ Pair 3} & TVA EXCL & 0,058961 & 1,18527928 & 0,12493940 & - & 0,30721364 & 0,472 & 0,638 \\
\hline & $\begin{array}{l}\text { Before } \quad \& \\
\text { After }\end{array}$ & 709 & & 6 & 0,18929023 & 8 & & \\
\hline
\end{tabular}

Source: Secondary data processed, 2021

From the results of the Trading Volume Activity paired test as seen in Table 4, the significant level of the three samples tested also showed a significant value higher than 0.05 , where TLKM had a significance level of 0.962 with $t$ count value of 0.048 , while ISAT showed a significant level of 0.292 with a $t$ count value of 1.061 and EXCL had a significant level of 0.638 with a $t$ count value of 0.472 . Therefore, based on the results of the paired sample test from these three samples it can be concluded that $\mathrm{HO}$ is accepted where there are no significant difference in TVA shares of telecommunication sector companies (TLKM, ISAT and EXCL) before and after the announcement of the first Corona Virus Disease 2019 infection in Indonesia. Thus the second hypothesis was also rejected. 


\section{First Hypothesis}

Based on the results of statistical tests and paired sample $t$ tests that have been conducted on the first hypothesis, it was found that there was no significant difference in the AR of telecommunication companies shares (TLKM, ISAT and EXCL) before and after Indonesia announced the first case of Covid-19 infection. This proves that the emergence of the Corona Virus Disease pandemic 2019 will not have a major impact on the performance of telecommunication companies in Indonesia. Especially during the implementation of Large-Scale Social Restrictions (PSBB) and the Enactment of Community Activity Restrictions (PPKM), where people are asked to be able to carry out activities and remain productive at home, so that internet services become a new staple in the pandemic period. The results of this study support an article written by (Niaz et al., 2021), where telecommunication companies such as Telkom recorded an increase in customer numbers and revenue in 2020 compared to 2019.

However, the average value of abnormal returns on telecommunications company shares decreased although it is not significant if we compare before and after Indonesia announced the first case of Covid-19 infection. Where the mean value of TLKM before the announcement of the first Covid-19 case in Indonesia is positive 0.006866153 while after it was announced positive 0.002363389 . Similarly with ISAT and EXCL which show decrease in the mean value from the previous positive 0.028241644 to positive 0.016133408 and positive 0.016133408 to positive 0.013524156. According to (Firli \& Rahadian, 2020), positive AR proves that the actual return obtained is higher than the expected return. In accordance with the performance of the three telecommunications companies, three of them were show growth of revenue during the pandemic period which result positive abnormally returns to investors even though it is not significant (Basmar et al., 2021).

2. Second Hypothesis

The results of statistical and paired sample t tests to the second hypothesis proved that there was no significant difference in TVA of telecommunication companies shares before and after Indonesia announced their first case of Corona Virus Disease. This indicates that there is no panic selling action on the telecommunications companies shares after the first Covid-19 infection in Indonesia. Which can be seen from the mean value of the three telecommunications company TVA that did not experience significant changes, for example TLKM whose mean value before the announcement of the first Covid-19 infection in Indonesia was at the position of 0.099525807 and afterwards at the position of 0.096137221, as well as ISAT and EXCL.

In accordance with what (Hardiyanti et al., 2021) said, that if the price and trading volume of the stock did not experience a significant difference, it indicates that the stock trend has not changed. In this case there is no significant difference in AR and TVA in telecommunication companies in Indonesia, it can be 
concluded that the stock trend of telecommunication companies in Indonesia has not changed before and after Indonesia announced the first case of Corona Virus Disease infection. The results found in this study also contradict the results of studies from (Hardiyanti et al., 2021) and (Machmuddah et al., 2020) which found significant differences in stock trading volume before and after the announcement of the first Corona Virus Disease in Indonesia.

\section{Conclusion}

The purpose of this study is to understand if there are abnormal differences in AR and TVA of telecommunication companies before and after the first announcement of Corona Virus Disease in Indonesia. Based on the results of the paired sample test conducted in this study, it can be concluded that for hypothesis 1 researchers found no significant difference in AR of telecommunication sector companies shares included on the Indonesia Stock Exchange before and after the announcement of the first Corona Virus Disease in Indonesia. This proves that the performance of Indonesian telecommunication companies is not affected by the Covid-19 pandemic, where the need for internet and telecommunication services is actually become the basic need for people to remain productive from home. This is reflected in the performance of these three telecommunications companies (TLKM, ISAT and EXCL) which can still record positive growth of revenue during pandemic period, which resulting in positive abnormal positive although it is not significant.

Similarly, for hypothesis 2, where researchers found no significant difference in TVA of telecommunication companies shares included on Indonesia Stock Exchange (IDX) before and after the announcement of the first Corona Virus Disease in Indonesia. This shows that there is no panic selling action in telecommunication companies shares after the announcement of the first Covid-19 infection in Indonesia. However, the results found in this study contradict to the results of previous researchers, who found significant differences in stock trading volume before and after the announcement of the first Corona Virus Disease 2019 infection in Indonesia. 
Analysis of Abnormal Return and Volume Activity of Telecommunications Sector Shares in Indonesia Before and After Covid-19

\section{BIBLIOGRAFI}

Aprillia, A. F. (2020). Pengaruh Covid-19 Terhadap Pasar Modal Indonesia Dengan Menggunakan Abnormal Return, Trading Volume Activity, Dan Market Capitalization (Event Study Pada Perusahaan Sub Sektor Transportasi Yang Terdaftar Di BEI). Skripsi, Universitas Muhammadiyah Magelang.Google Scholar

Announcement Of Covid-19: Event Study In Indonesia. Journal Dimensie Management And Public Sector, 2(2), 25-32.

Basmar, E., Purba, B., Nugraha, N. A., Purba, E., Krisnawati, L., Damanik, D., Hariyanti, A. I., Banjarnahor, A. R., Elistia, E., \& Sahir, S. H. (2021). Perekonomian Dan Bisnis Indonesia. Yayasan Kita Menulis. Google Scholar

Candra, S., Ayudina, M., \& Arashi, M. A. (2021). The Impact Of Online Food Applications During The Covid-19 Pandemic. International Journal of Technology, 472-484. Google Scholar

Fajriani, I. (2021). Pengaruh Penggunaan Aplikasi Google Classroom Terhadap Motivasi Dan Prestasi Belajar Ipa Saat Pandemi Covid-19 Di Smp Islam AzZamir Tangerang Tahun Pelajaran 2020/2021. Google Scholar

Faulan, M. R. (2020). Pengaruh Covid-19 Terhadap Nilai Saham Perusahaan Transportasi Di Bursa Efek Indonesia. Google Scholar

Firli, A., \& Rahadian, D. (2020). Analysis Of The Impact Of Terrorist Bombing Acts On Abnormal Return And Trading Volume Activity: Study Of Terrorist Bombings. Google Scholar

Hardiyanti, R. T., Septiyanti, R., \& Dharma, F. (2021). Market Reaction To The. Google Scholar

Machmuddah, Z., Utomo, S. D., Suhartono, E., Ali, S., \& Ali Ghulam, W. (2020). Stock Market Reaction To COVID-19: Evidence In Customer Goods Sector With The Implication For Open Innovation. Journal Of Open Innovation: Technology, Market, And Complexity, 6(4), 99. Google Scholar

Niaz, A., Karunia, J., Mandwie, M., Keay, K. A., Musumeci, G., Al-Badri, G., \& Castorina, A. (2021). Robust Dopaminergic Differentiation And Enhanced LPSInduced Neuroinflammatory Response In Serum-Deprived Human SH-SY5Y Cells: Implication For Parkinson's Disease. Journal Of Molecular Neuroscience, 71(3), 565-582. Google Scholar

Rahmayani, D., \& Oktavilia, S. (2020). Does The Covid-19 Pandemic Affect The Stock Market In Indonesia? Jurnal Ilmu Sosial Dan Ilmu Politik, 24(1), 33-47. Google Scholar 
Sumadi, Dewi Tamara, Purba Yudha Tama, William

Sutrisna, T. (2020). Flashback: What Happened In DKI After The First Case Of Covid19 Was Announced.

Utami, D. N. (2020). Indihome Customers Thrive In Pandemic Times. Market.Bisnis.Com.Https://Market.Bisnis.Com/Read/20201022/192/1308350/Pe langgan-Indihome-Tumbuh-Subur-Di-Masa-Pandemi.

Utomo, M., Buchari, H., Banuwa, I. S., Fernando, L. K., \& Saleh, R. (2020). Carbon Storage And Carbon Dioxide Emission As Influenced By Long-Term Conservation Tillage And Nitrogen Fertilization In Corn-Soybean Rotation. Journal Of Tropical Soils, 17(1), 75-84. Google Scholar

Worldwide (2008-2017). In Advanced Issues In The Economics Of Emerging Markets. Emerald Publishing Limited. Google Scholar

Yeremia, A. E. (2021). Explaining Indonesia's Constrained Engagement With The Belt And Road Initiative: Balancing Developmentalism Against Nationalism And Islamism. Asian Perspective, 45(2), 325-347. Google Scholar

\section{Copyright holder:}

Sumadi, Dewi Tamara, Purba Yudha Tama, William (2021)

\section{First publication right:}

Syntax Idea

\section{This article is licensed under:}

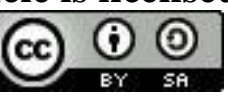

